\title{
Discrimination And Its Effects: A Case From Health Care Institution
}

\author{
Ghazal Khawaja Hummayun Akhtar \\ \& \\ Sunerah Iqbal \\ Department of Public Administration \\ University of Karachi
}

Muhammad Shahid

Department of Social Work

University of Karachi

\begin{abstract}
Gender discrimination persists in contemporary work places very frequently in various manners and of diverse nature. Although current human resource practices tried to disregard this evil and make healthier work place. Gender discrimination is not only relates to women, it also distresses men as well. But in our society its ultimate targets are women. This research tends to explore the ratio between male \& female who are fronting gender discrimination at work place. The purpose is to draw attention to the relationship among gender discrimination at work place and its effects on the level of satisfaction, motivation, commitment, enthusiasm \& stress level. Moreover, it also highlighted the main harasser and different ways harassment take place at workplace. For this study health care organization has been chosen because it makes an important contribution to economic and social progress of the country moreover; most of the work force consists of females.
\end{abstract}

Key Words: Case Study, Gender Discrimination, Effects, Harassment, Causes

$$
\begin{aligned}
& \text { تلخيص }
\end{aligned}
$$

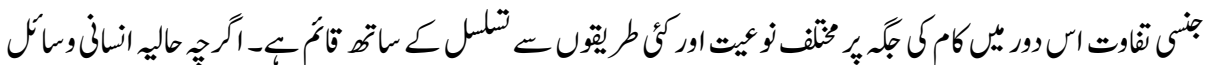

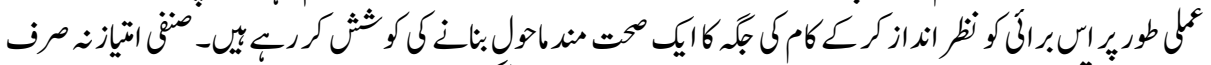

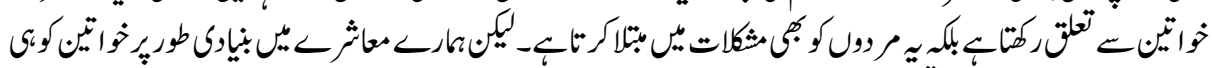

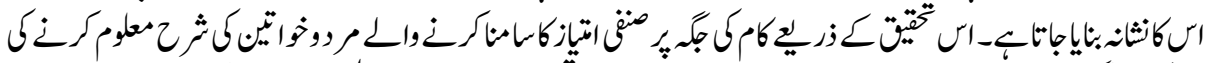

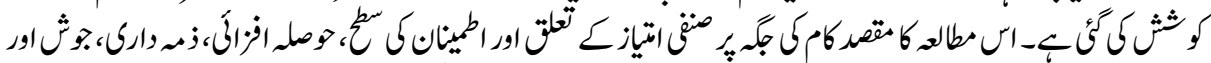

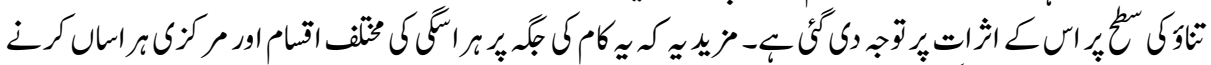

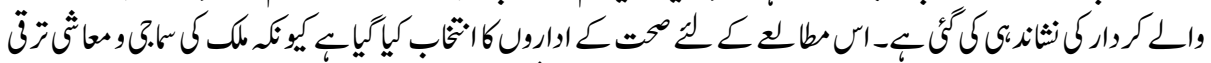

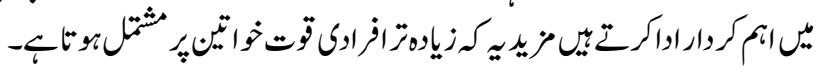

$$
\begin{aligned}
& \text { كليرى الفاظ: سواخى مطالد، جنى اتتياز، اثرات،براسالكرنا،وبوبات }
\end{aligned}
$$




\section{Introduction}

Discrimination is a mindset which impediments may start in the family \& extended to the whole period of work life. Large number of cases reported in developing countries particularly. It is more a psychological dilemma in a patriarchal society like Pakistan. However, socio-economic status of women, religious values and restrictions, lack of attention and indifferent attitude of governments are the key triggers of the situation. Current international practices of human resources respecting the diverse workforce and encourage implementing conducive and congenial environment particularly for women. More work needed to be done in the implementation mechanisms to avoid any failure in results. This piece of study tends to figure out the ways and processes which create gender inequality. The study is conducted in two principal approaches. Theoretical frame work was established by information gathered from relevant materials like case studies, reports and articles on gender issues. Moreover, independent survey was that carried out from 110 full time management staff of a leading health care institution in Karachi. Through proportionate random sampling 55 male \& 55 female respondents were asked collectively one open ended and nine close ended questions. Both theoretical framework and primary data help the researchers to identify the prejudice victims and its negative effects in work setting.

\section{Literature Review}

Women at workplace are now the most debated issue around the world. Current human resource practices tries to frame policies which provide sufficient and equal opportunities to all. The question which trouble us that whether we rejoice the $104^{\text {th }}$ International women's day with all determinations and recognition of women by world or should we concentrate on those elements of women where they are constantly struggling for their identity.

Discrimination refers to "any situation where a person is denied an opportunity or misjudged solely on the basis of sex. Discrimination is any unequal treatment based on gender. The basic feature of gender discrimination is evident in any situation where a person shows a prejudice towards another that would not occur had they been the opposite sex" (Koss, 1993).

However, gender discrimination may be explained as the partially or biasness that an individual faces because of his/her sex. Discrimination is the detrimental treatment of an individual based on their actual or perceived membership in a certain group or category, "In a way that is worse than the way people are usually treated" (Curtis, 2006). 
Health care refers to the service providing sector for the prevention \& treatment of disease and for the promotion of physical \& mental well-being. A health care system of any country is the reflection of their culture, mindset, attitudes, values and life style of the society. In 2002, the International Labor Organization, International Council of Nurses, WHO, \& Public Services International (ILO/ICN/WHO/PSI) Joint Program on violence in the health sector defined workplace violence as: "Incidents where staff is abused threatened or assaulted in circumstances related to their work, including commuting to \& from work, involving an explicit or implicit challenge to their safety, wellbeing or health." (Curtis, 2006).

Health care industry today has emerged as one of the most challenging as well as one of the largest service provider industry. Evidences prove that vulnerability of gender inequality is high in health sector since it is one of the large service sectors with majority female employees. The ILO/ICN/WHO/PSC Joint Program Report draw attention to that both sex in work setting seemed to be at risk of discrimination. However, women could be more vulnerable victim of violence in the health sector (Constance J Newman).

Recent studies elucidates that gender bigotry affects men at work place too. Researchers sent off 2 fake applications for more than 400 jobs in the 4 professions. Each applicant had equal experience, qualifications \& age profiling one with a man's name and other bore a woman. Men were nearly 4 times less likely to get an interview for the secretarial posts (International Council of Nurses: ICN Nur Cooper C) However, one recent survey found, it will take 40 years for women to achieve equality in the boardroom (Constance J Newman).

Gender discrimination at work place can be classified from different points of view which are as follows:

\section{Pecuniary/ Monetary Bias}

The most common and complained one is economic disparity. This generally happen during pay fixation process or at the time of actual payment. It is common observation that women mostly receive low payments/salary as compared to men.

\section{Biasness as to Opportunities}

Hindering the promotion and show reluctances in giving equal employment opportunities is the most noticed attitude of employers. Barrister Harun-ur-Rashid, former Bangladesh Ambassador to the UN, Geneva, writes in the law page of the Daily Star on 13th March, 2010, that out of 4419 civil servants, only 673 are women, according to the establishment ministry. There is only 1 woman DIG of police \& 4 female additional DIG's in the police force (AfrozaBilkis, July-December 2010). 


\section{Personal Bias}

Favoring or giving undue importance to some workers at workplace stimulates a hostile environment for others \& especially for the females. The worst form of personal biasness is observed in unduly taking advantage of female employees \& workers through sexual harassment.

\section{Authority Bias}

Another common trend found in organizations that they reserve powerful \& influential positions for men only. Women are subject to hold lower level in hierarchy and supervise fewer subordinates and are less likely to control financial resources (Koss, 1993).

An organization could gain profit from ensuring workers have job satisfaction such as improved morale of workers, good working environment, friendly co-workers, supportive supervisor (YoditTesfaye, 2010).

All the studies pointed out to a healthy working environment for both men and women so that they will get motivated, producing better results for the companies as a whole. Research revealed that harassment at workplace can lead to an overall decrease in employee motivation towards the job resulting in increase in absenteeism, turnover \& request for transfers leading to decrease in overall productivity (Constance J Newman).

If an employee is discriminated by his/her boss/colleagues then his/her motivational level will be diminished, he may suffer from a sense of loss of dignity and strong resentment \& then he won't be able to focus on his tasks \& duties he will be in stress \& he won't feel relaxed \& contended \& this will result in bad attitude, poor performance \& ultimately lead to low productivity of the organization. Moreover, employees are less likely to work in a team with less respect and unequal treatment. Workers might involve into conflicts with one another when treatment is not fair. They might seek employment at another establishment where they feel they will be treated fairly. The reputation of the business might be jeopardized and the company loyalty compromised when employees are subject to gender bias.

\section{Research Findings}

This research article discovers the concerns of gender discrimination at work place \& purposes at detecting the direct \& indirect effects on organizations productivity. 110 respondents were asked eleven questions to get the insight of this social dilemma; discrimination at workplace. 


\section{Statement \# 01}

\section{Victims of Discrimination}

It is very surprising to identify that not only females but males also faced discrimination at work place as $75 \%$ male and $\& 78 \%$ females responded positive to answer of facing discrimination. See Chart 1:

\section{Chart \# 1}
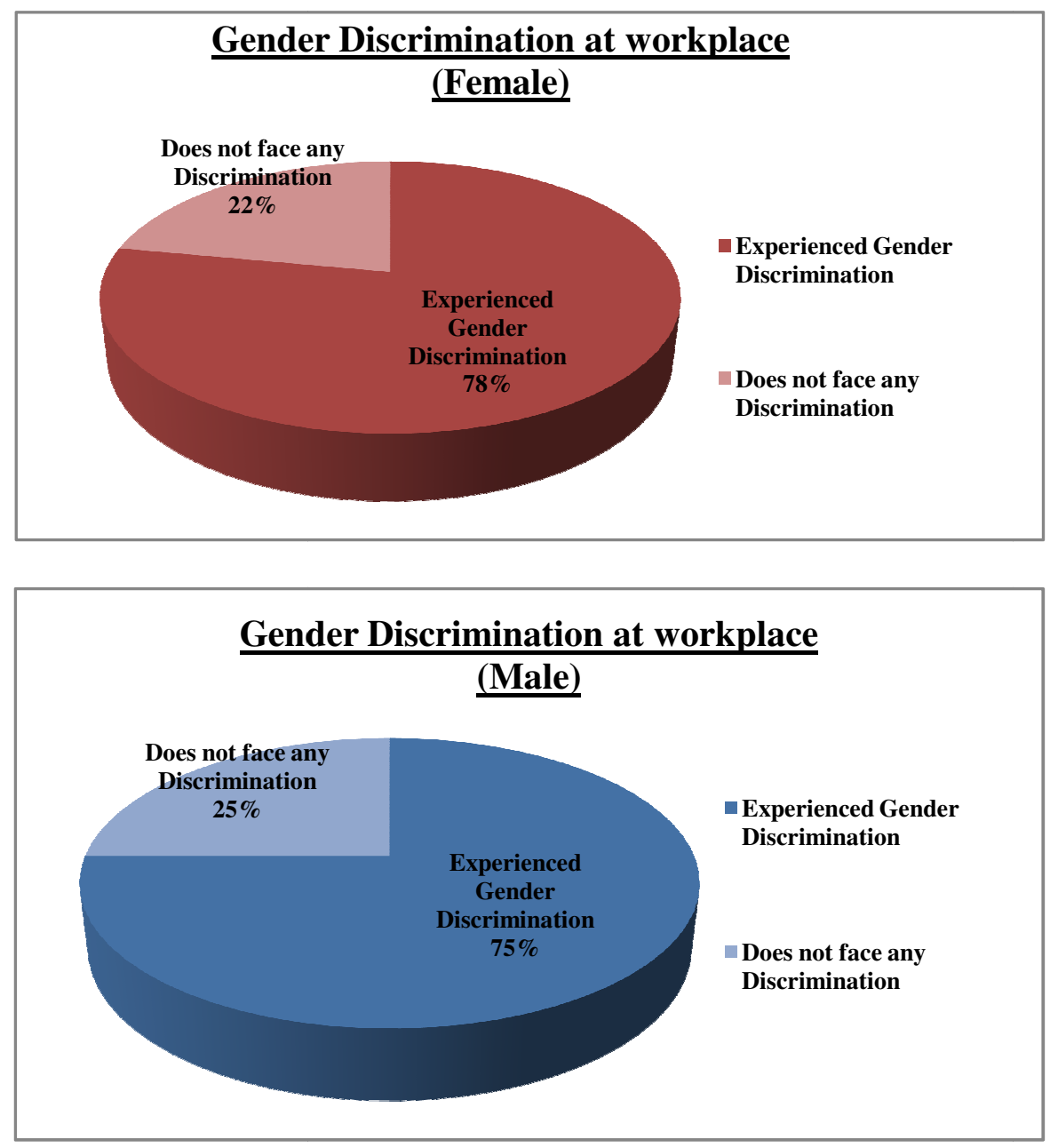

\section{Statement \# 02}

\section{Kind of Discrimination Faced}

According to the responses generated at the workplace, 'biasness' is the most noticeable trend faced by majority employees. Moreover, female workers are mostly victim of sexual harassment and unequal employment opportunities. See Chart 2 
Chart \# 2
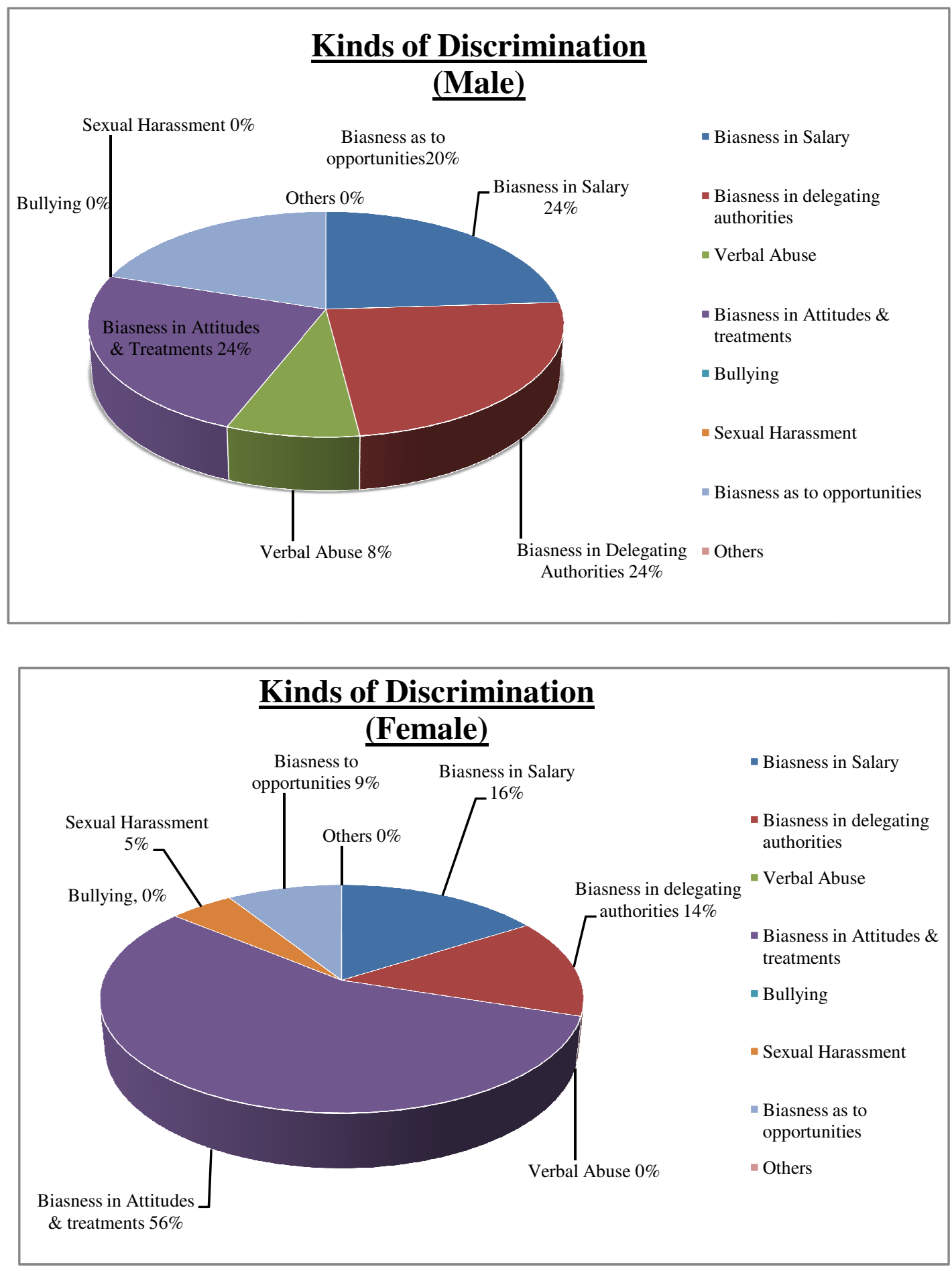


\section{Statement \# 03}

\section{In Terms of Incentives, What do You Feel You are Most Discriminated in}

This question was divided into intrinsic and extrinsic rewards. Male responded mostly face discrimination in project leads and females face biasness in getting promotion opportunity. See Chart 3

\section{$\underline{\text { Chart \# } 3}$}
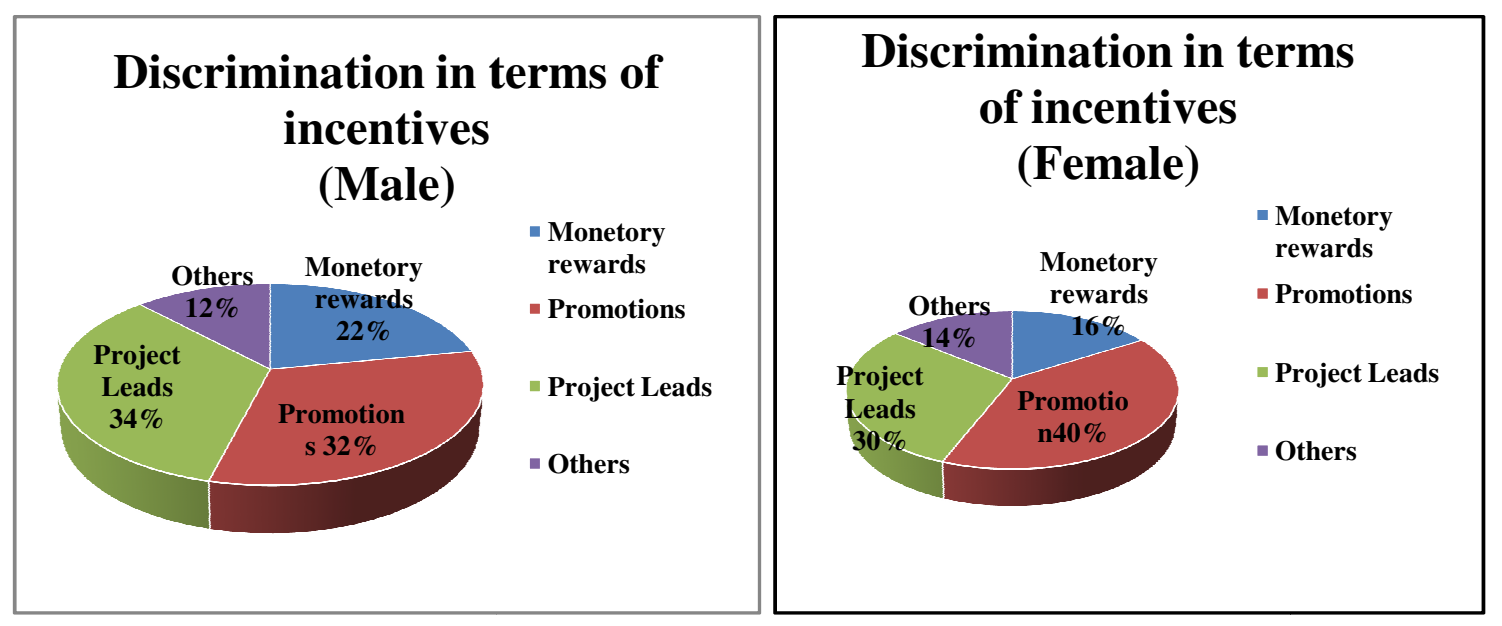

\section{Statement \# 04}

\section{Main Harasser at Your Workplace}

According to respondents, as far as the main discriminator is concerned, immediate supervisor \& colleagues do not co-operate to keep a discrimination free environment. See Chart 4.

\section{Chart \# 4}

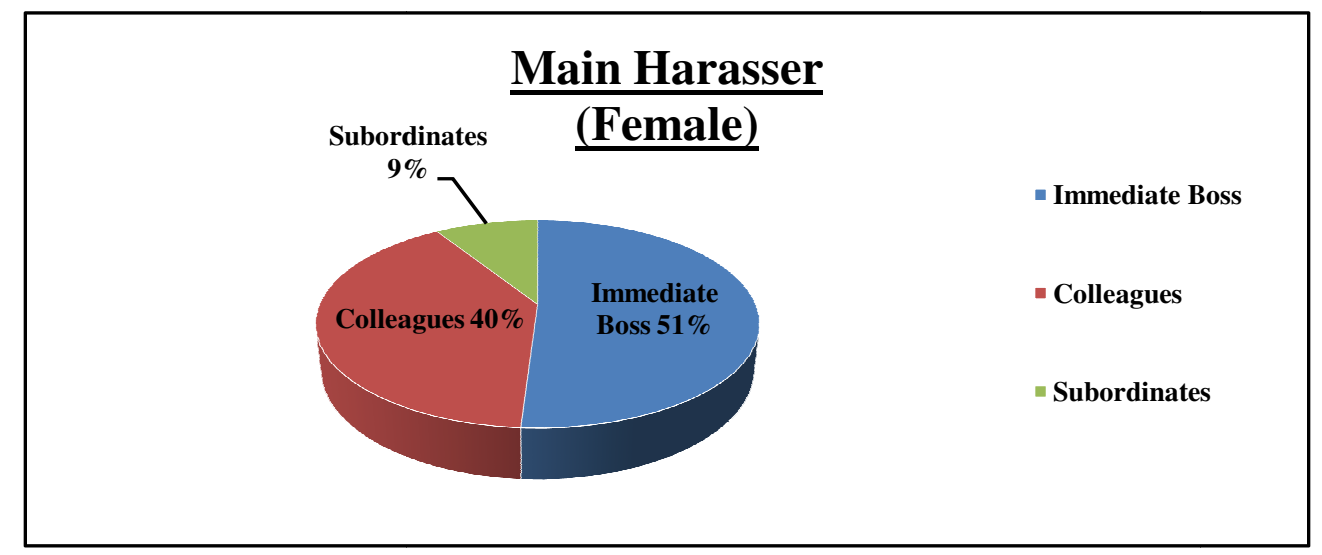




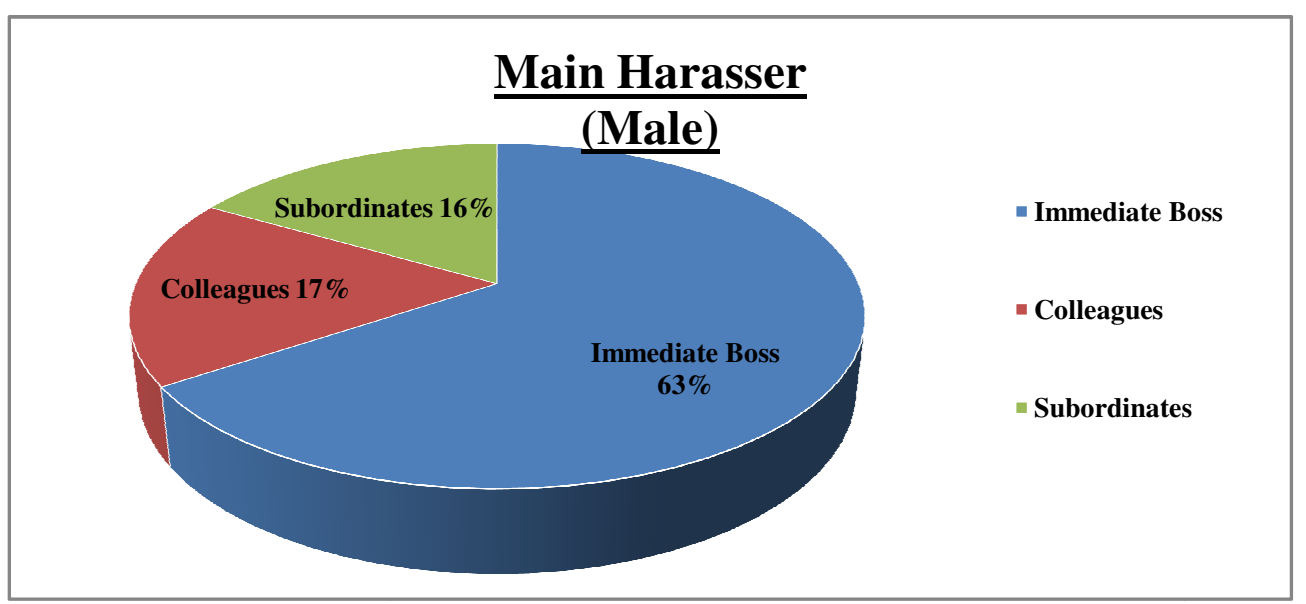

\section{Statement \# 05}

Most Contributing Factor in Creating Discriminatory Environment at Workplace

Mostly male respondent are of view that preconceived notion of our society to accept biased attitude is the main contributing factor of discrimination at workplace. Moreover, females consider the low socio-economic status of women in our society is the most contributing factor. See chart \# 5

\section{Chart \# 5}

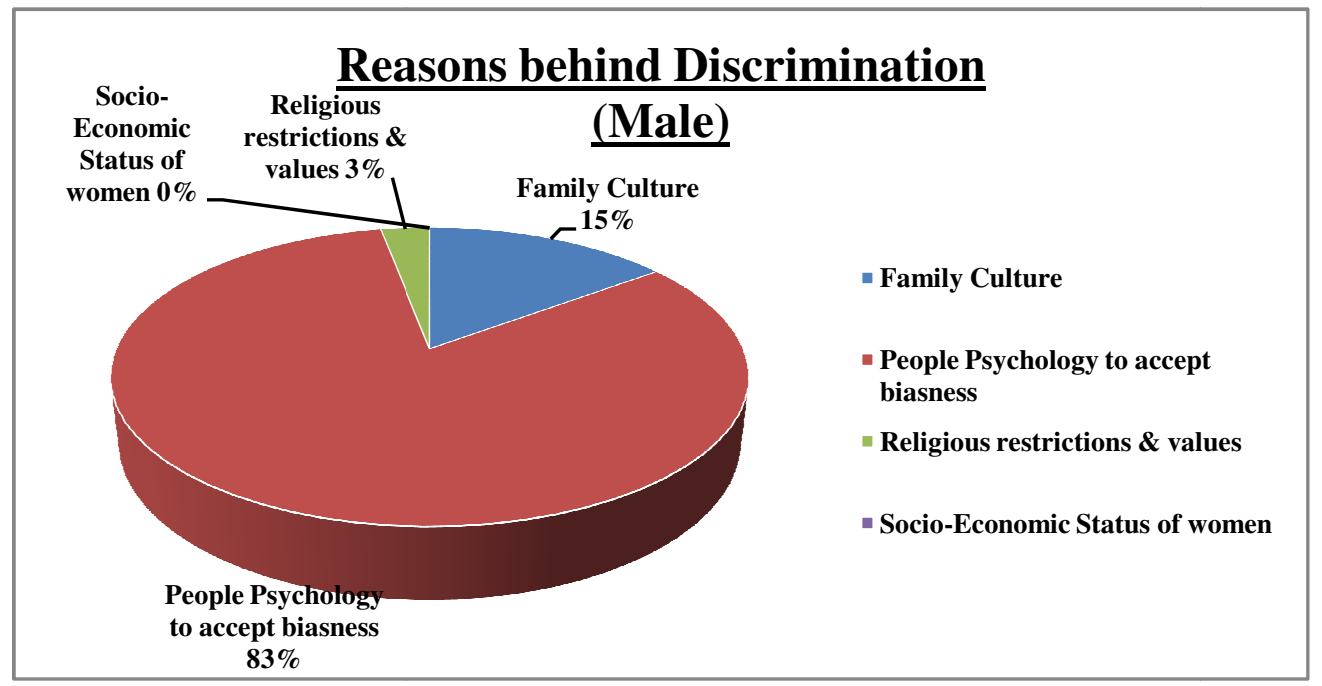




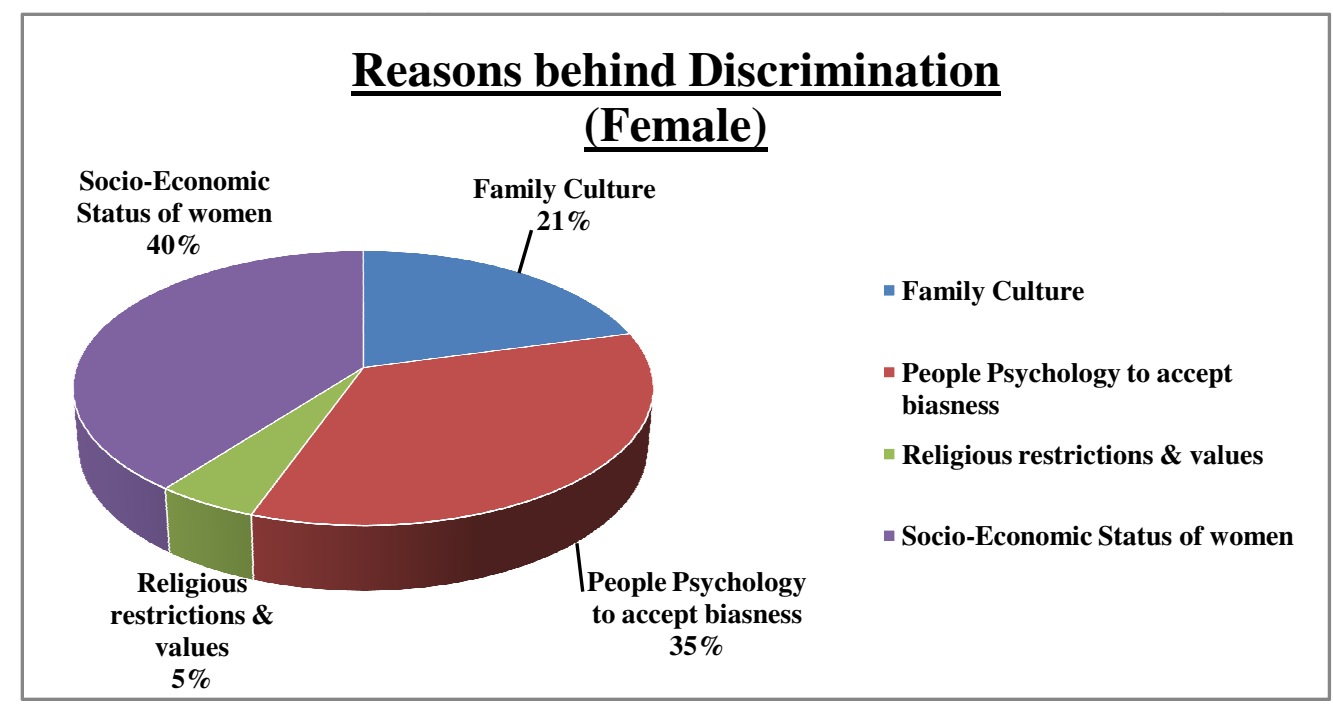

\section{Statement \# 6}

\section{The Effects of Discrimination}

Highest number of male responded that they encounter depression and stress which eventually leads to resignation from job. Female workers consider it more traumatic \& interpersonally disruptive that results into lack of motivation to perform duties.

\section{Statement \# 7}

\section{The Government Role in Discrimination Free Work Environment}

Policy makers of our country could effectively play their role in fighting against discrimination at workplace but our respondents do not believe much in governemnt policies. They are of opinion that government of Pakistan is not serious in eliminating this deep rooted evil from our society. See Chart \# 7 


\section{Chart \# 7}
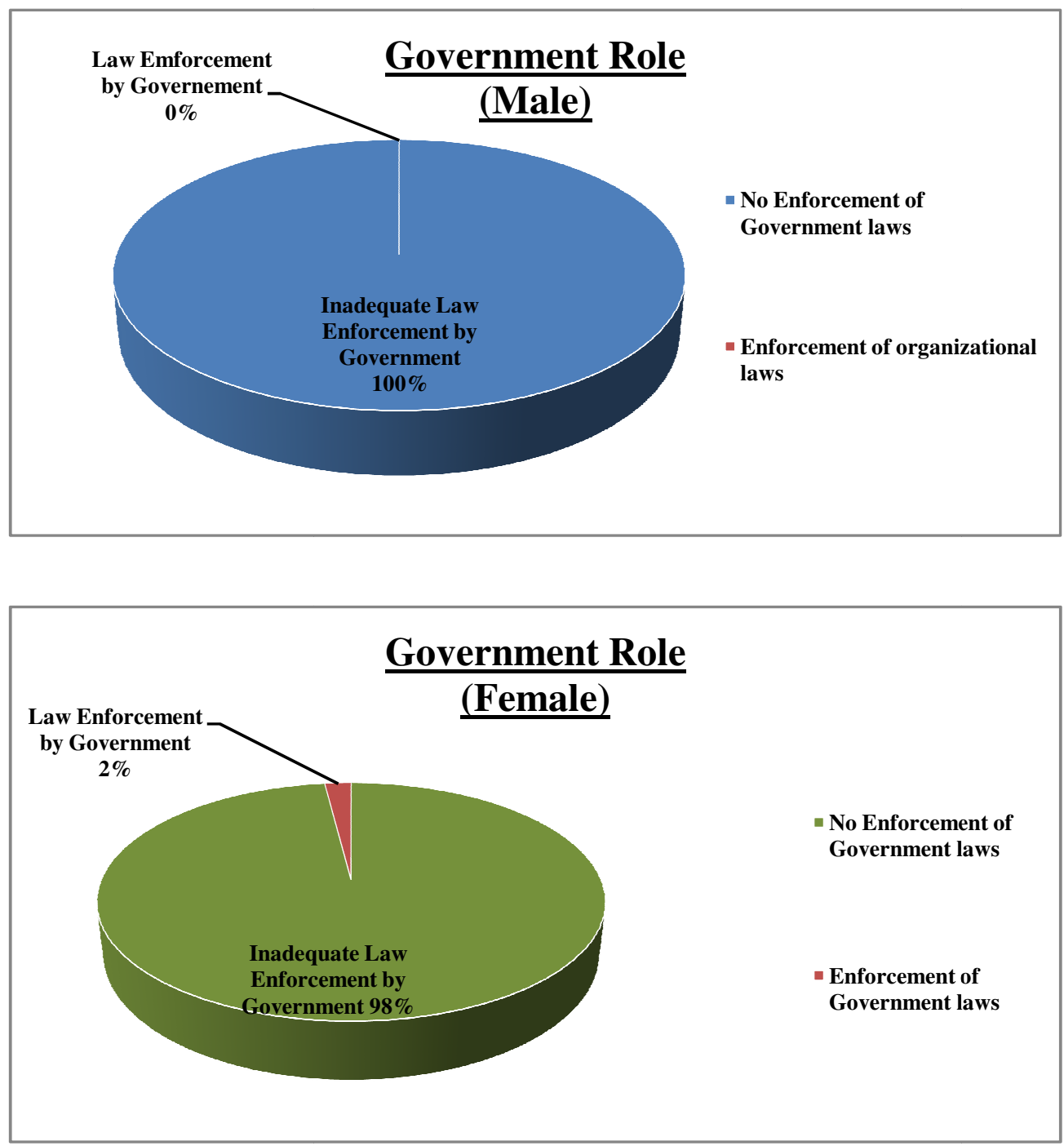

\section{Statement \# 8}

\section{Organization Role in Implementing laws on Harassment at Workplace}

$100 \%$ male \& $95 \%$ females are of opinioned that organization does not have proper guideline to handle discrimination at workplace. They said there is no enforcement of any organizational laws to deal with the situation. See chart \# 8 


\section{Chart \# 8}
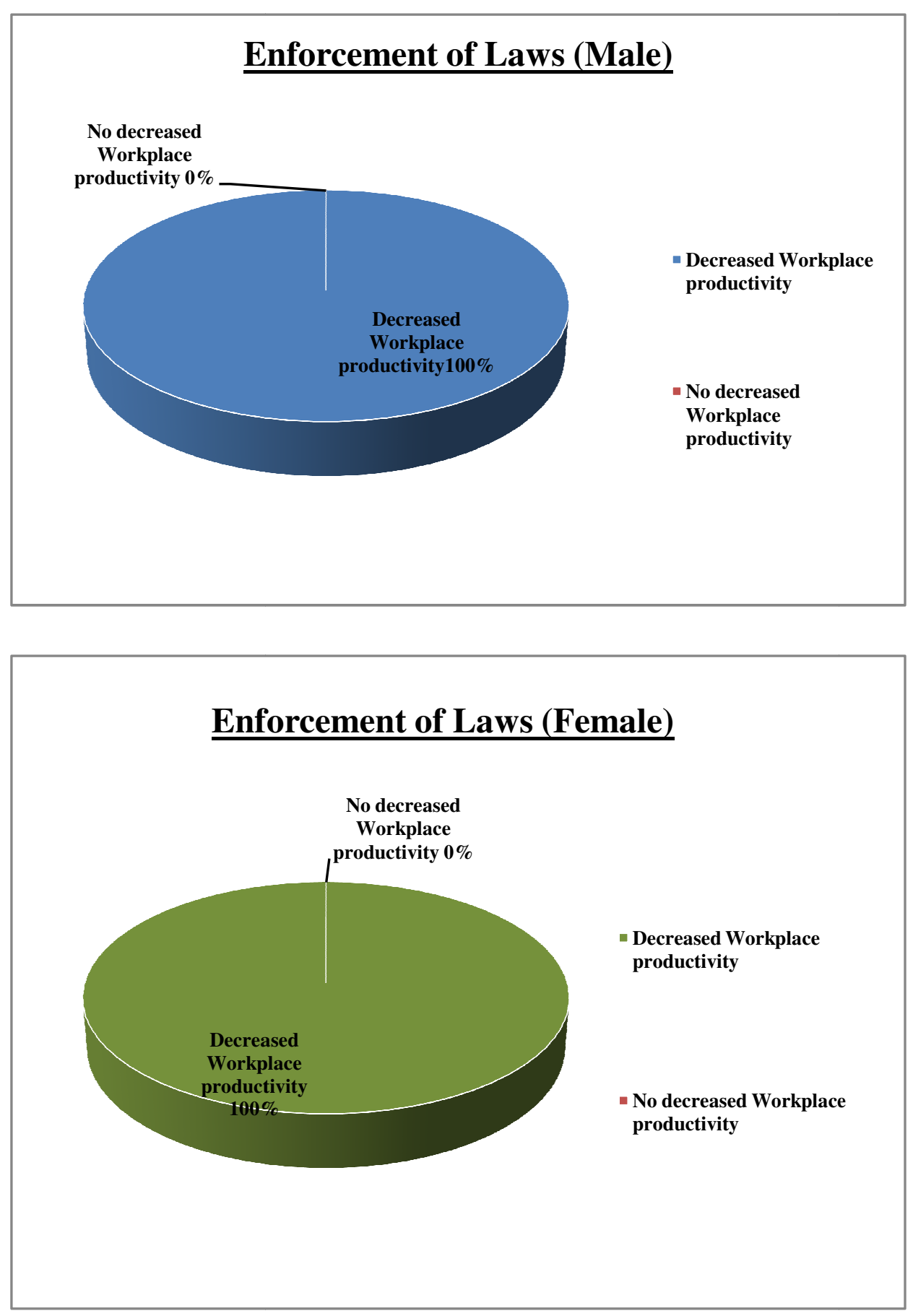


\section{Statement \# 9}

\section{Empowered and Motivated to Take Decision}

$71 \%$ male responded that decisions are taken by both gender, however, only $63 \%$ females given the same opinion. See Chart \# 9

\section{Chart \# 9}
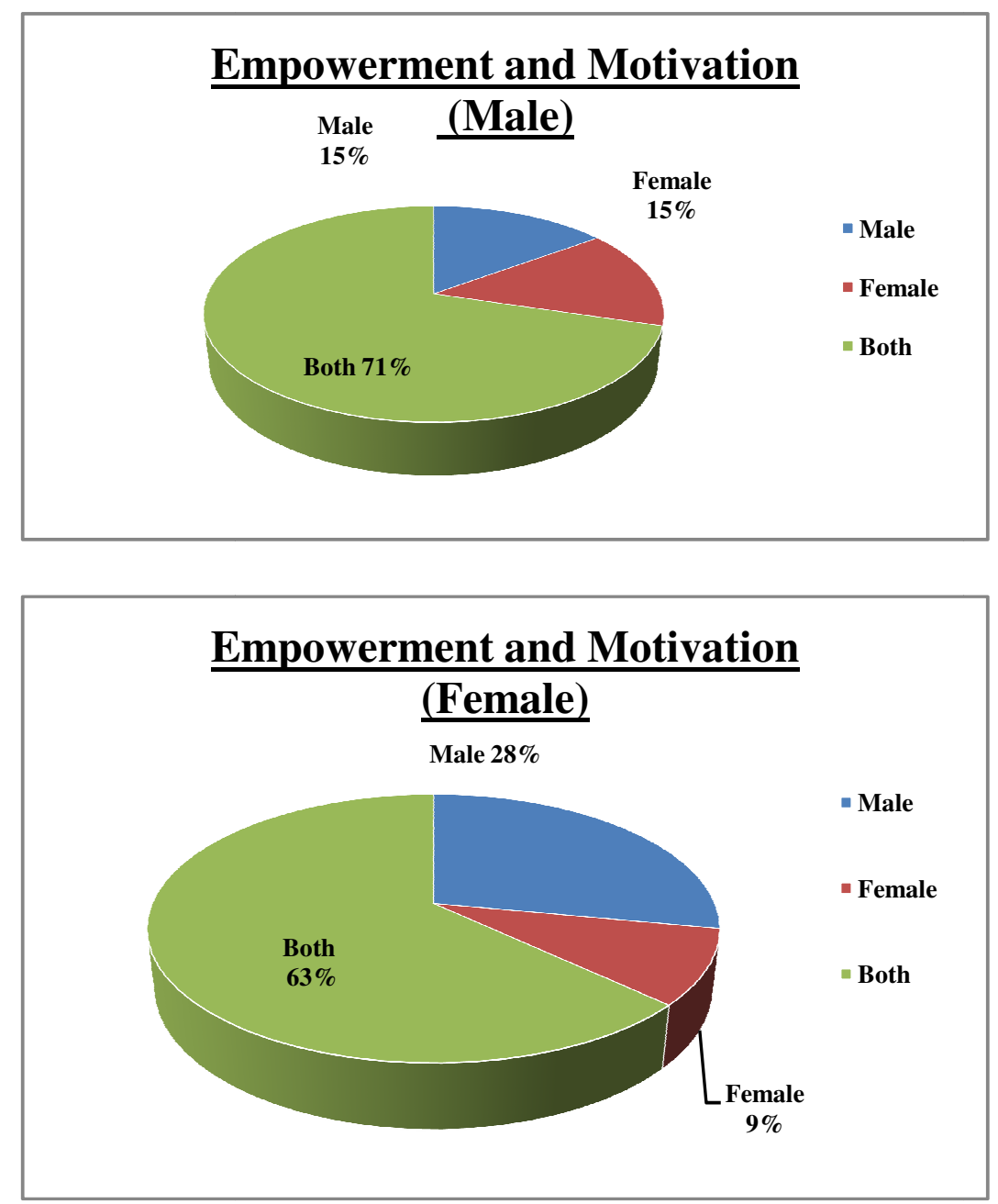

\section{Discussion \& Analysis}

The thorough analysis of literature and subsequent survey revealed that discrimination at workplace is faced by both gender but it critical target the female employees. The most alarming element is the socio-economic status of women in our society \& the people's 
mind set to accept discrimination. The outlook of discrimination is generally in terms of attitudes \& treatments. It is observed that this is the time to change our mindsets \& should raise our voice whenever we encounter discrimination or if it happens around us. Responses showed that main harasser at the workplace are usually the immediate bosses which result into low productivity and motivation of an employee. Even though the organization has made several policies but there is no execution of those policies. It is pointed out that the government should play its role in not only framing but also the enforcement of laws against discrimination and harassment in work settings.

\section{Suggestions}

Some recommendations may be made on the basis of different available facts \& the independent research:

- Women should take initiative to empower themselves \& advance their skills by proving their equal status as individuals \& educating themselves.

- Women should have confidence on themselves \& if they are facing any sort of discrimination they should raise their voice against it so that it won't occur next time with anyone else.

- Women should apply for the jobs having more authority \& responsibility \& hence having high salaries.

- Women should hire \& promote as well as guide /mentor other women to become leaders \& managers.

- Government \& different NGO' should take steps to upgrade the position of women \& eliminate the gender discrimination by imposing the existing laws or by making new laws giving equal opportunities to both men \& women.

- Systematic surveys \& statistics by government officials \& NGO's should be done to give better insight into the existing \& actual scenario.

- Government must incorporate the dimensions of gender equality into national development planning \& budgeting. Moreover, proper mechanism should be devised to implement various laws for promoting equal treatment at work place.

- Government should expand knowledge \& awareness on gender equality among people through electronic and print media like; advertisements, banners, pamphlets or through workshops \& mandatory trainings.

- Equality at workplace should be given priority. Violence research should be a routine activity of human resource department to systematically monitor gender discrimination.

Taking actions on the forgoing will require a long way in transforming safer and gender equitable work environment but it increases the retention of productive workforce at health care. 
- Human Resource policies must guard women against violence as well as against losing seniority, promotions, project leads based on their gender.

- HR must ensure that ongoing trainings \& workshops should be organized for all employees including management as well. If any incident is reported to them they should conduct full investigation \& should take necessary actions against the lawbreakers \& set the examples for others.

- At the end I would like to recommend the people that please stop being a part of gender discrimination as a discriminator $\&$ as a victimized as well.

\section{Conclusions}

The fact has been established that both; male and female encounter discrimination at workplace. The main key factor which contributes towards the discrimination is the institutional \& behavioral rather than individual. The discrimination leads to demotivation, lost enthusiasm \& morale which is very necessary to accomplish job results. Lower productivity further leads to absenteeism or resignation that results into the loss to the organization and ultimately ruins the economic growth of the country. If management \& HR enacts \& enforce upgraded policies, it is likely that discrimination could decrease to some extent.

However, women workforce has successfully managed to attain equal status \& recognition in many sectors of employment in our country. But still in many ways our religious, social, political, cultural \& especially our psychological aspect is the main hindrance for them to achieve deserving status. They tend to accept biasness \& discrimination in employment and status-quo maintained in our society.

It is the need of time to eliminate discrimination and construct a congenial work environment. Moreover, organizations should work hard to develop productive and motivated female employees that deliver their full potential, skill and knowledge to improve the standard of living of their families and also become the main contributor into the economic growth of the country.

\section{References}

AfrozaBilkis, Shamima Binte Habib \& Tasnuva Sharmin (2010). A Review of Discrimination in Employment \& Workplace: ASA University Review, vol. 4 (2).

Cambridge Dictionaries, Online Cambridge University Retrieved 29 March 2013. 
Cheryl L. Wade: "Transforming discriminatory Corporate Cultures" http://digitalcommons.law.umaryland.edu/cgi/viewcontent.cgi?article=3250\&cont ext=mlr

Cooper C, Swanson N (2002). Workplace Violence in the health sector: State of the art, Working Paper Geneva, Switzerland, ILO/ICN/WHO/PSI Joint programme on Workplace Violence in the health sector.

Constance J Newman, Daniel H de Vnies, Jeanne d'ArcKanakuze \& Gerard Ngendahimana (2011). Workplace Violence \& gender discrimination in Rwanda's health workforce: Increasing Safety \& gender equality, http://www.human-resources-health.com/content/9/1/19

Gutek, B. A. \& Koss, M. P. (1993). Changed women and changed organizations: Consequences of and coping with sexual harassment. Journal of Vocational Behavior, 42: 28-48.

International Council of Nurses (2002). ICN Nursing Matters fact sheet. Violence a worldwide epidemic. Cooper C, Swanson N: Workplace Violence in the health sector: State of the art. Working paper Geneva, Switzerland: ILO/ICN/WHO/PSI Joint Programme on Workplace Violence in the Health sector.

International Labor Office (2002). International Council of Nurses, World Health Organization, Public Services International: Framework Guidelines for Addressing Workplace Violence in the Health Sector, Geneva, International Labor Office.

Judith E. Grey-Bowen, Miami-Dade County Public Schools, Donovan A. McFarlane (2010). The Donovan Society LLC \& Frederick Taylor University: Gender Discrimination: An Exploration of Gender compensation Gap \& the Higher Education Connection: Journal of Business Studies Quarterly: vol. 2, pp. 65-82.

Polly Curtis (2006). Sex discrimination at work hits men too: The Guardian.

Shilpee Adhikari (2014). Impact of Gender Discrimination at Workplace: Journal of Education, vol. 21 (4): pp. 2347-8225.

Yodit Tesfaye, Rebecca Kihlman (2010). The effects of discrimination on job performance \& job satisfaction, http://www.theseus.fi/xmlui/bitstream/handle/ 10024/38525/Tesfay\%20Yodit\%20Dissertation.pdf?sequence $=1$ 
Dr. Ghazal Khawaja Hummayun Akhtar is Assistant Professor in the Department of Public Administration, University of Karachi.

Ms. Sunerah Iqbal is MS Student in the Department of Public Administration, University of Karachi.

Dr. Muhammad Shahid is Associate Professor in the Department of Social Work, University of Karachi. 